\title{
Racism, Ethnic Discrimination, and Otherness in Shakespeare's Othello and The Merchant of Venice
}

\section{Shaghayegh Moghari}

\begin{abstract}
This study aims to present a comparative examination of the traces of racism and discrimination in two plays of Shakespeare, Othello and The Merchant of Venice, written in 1603 and around 1598, respectively in the Elizabethan Period. The attempt in this paper is to explore the construction of racism and the evidences of discrimination as depicted in Othello and the Merchant of Venice by use of the deconstruction of marriage. For this purpose, it deconstructs the marriage by focusing on Othello in Othello, and The Prince of Morocco in The Merchant of Venice; and, depicts racism and discrimination by comparing the characterizations of Othello in Othello and Shylock in The Merchant of Venice. Both sections critique the cruel issues these people experienced as other. The notion of 'otherness' and its application in the characterizations of Othello and Shylock, Othello vs. Shylock, the application of deconstruction of marriage to Othello and The Prince of Morocco, and racism in Othello and The Merchant of Venice are among the major items on which this article elaborates following by a conclusion describing the role of human conscience in racial and religious discrimination.
\end{abstract}

\section{Keywords}

Deconstruction, Racism, Shakespeare, Marriage, Otherness 


\title{
Racism, Ethnic Discrimination, and Otherness in Shakespeare's Othello and The Merchant of Venice
}

\author{
Shaghayegh Moghari
}

\section{Introduction}

There are many cases of marriages in the world of Shakespeare both in tragedies and in comedies. Some of the marriages are based on love, some are based on money, and some are based on race. However, there are marriages through which Shakespeare marginalizes others. Two cases here in this study, one from comedies and one from tragedies, are Othello and The Merchant of Venice by which the texts themselves deconstruct themselves. Through the application of the theory of deconstruction to these two plays we come to the conclusion that marriage becomes a cultural occasion by which Shakespeare proves the superiority of the European race and the inferiority of the African race. Through these marriages, he reinforces the dominant discourse of Elizabeth and western metaphysics which bases their existence on logo-centrism and binary oppositions like white and black, day and night. In these binary oppositions in Shakespeare there is always the superiority of the first term over the second one. For example, in the binary opposition of European and African, west and East the first one is given priority over the second. This dichotomy is also projected in literature. Through his plays, Shakespeare reflects how it is not possible for Africans to integrate with Europeans. Black and white is one binary opposition in these two works in which two black African are marginalized, humiliated, and othered because of their skin color.

This study examines how marriage is a kind of discourse in Shakespeare in order to further marginalize other races. The nature of marriages in the plays reveals much about racism during the time of Shakespeare. Shakespeare sometimes says something through marriages. In the case of Othello the marriage is considered to be against nature thus giving priority to Desdemona as the self in the dichotomy of self/other relation. The word marriage lends itself very well to the duality of self /other and the marriage of self and other is wrong. That is to say the duality of self and other in terms of skin color is something which should happen as Shakespeare implies in these two famous works.

In addition to analyzing 'othering' of Othello and The Prince of Morocco by the application of the deconstruction of marriage to them, this study aims to compare and contrast the characterizations of Othello and Shylock in the Shakespearean plays, Othello 
and The Merchant of Venice, in order to expose the unfair traces of racism and discrimination prevalent in the Elizabethan period which are represented in the two great literary works of Shakespeare.

\section{The Notion of 'Otherness'}

'Otherness' is manifested through different means. It can be rooted in cultural experience, race, or skin color. It is actually the result of a system of thought in which a hegemonic, dominant group creates one or several other minor groups named as 'them' or 'Other' by highlighting the differences as motives for discrimination, bias, and aggression. Consequently the process of 'othering' is precisely related to domination and power-relations that almost always stems from social, economic, and political inferences. In this article, the emphasis is on the distinction between 'difference' and 'Otherness'. 'Difference' is an essential part in the formation of meaning for a range of theoretic disciplines.

In anthropology, "culture depends on giving things meaning by assigning them to different positions within a classificatory system. The marking of 'difference' is thus the basis of that symbolic order which we call culture" (Hall 236). 'Difference' is then based on some facts, and this process of 'Othering' has always been thoroughly related to the ideology which is related to a set of false thoughts and beliefs "which serve to perpetuate a particular social formation or power structure; typically this power structure is itself represented by that ideology as eternally or naturally given - i.e. as inevitable, immutable." (Dollimore9). In this regard Staszak explains that:

The creation of otherness [...] consists of applying a principle that allows individuals to be classified into two hierarchical groups: them and us. The outgroup is only coherent as a group as a result of its opposition to the in-group and its lack of identity. This lack is based upon stereotypes that are largely stigmatizing and obviously simplistic. The in-group constructs one or more others, setting itself apart and giving itself an identity. Otherness and identity are two inseparable sides of the same coin. The Other exists only relative to the Self, and vice versa. (Staszak 43)

The concept of 'Otherness' is regarded as an undying and worldwide occurrence; it is inseparably connected to unbalanced power, economical, and political relations. Exclusively the more powerful and dominant group is authorized to prioritize and value its own thoughts and systems and to devalue and degrade those of less powerful others at the same time. They inflict unfair, discriminatory, and biased measures. So, the dominated out-group converts into a minor group labeled as 'Other' becoming subject to the defaming and unfair actions and thoughts of the hegemonic, cruel in-group which categorize them as out-group. 


\section{'Otherness' in the Characterization of Othello and Shylock}

The definitions of the 'Other' in sixteenth-century England were basically the manifestations of "an emblematic figure, not a "naturalistic "portrayal" (Vitkus160) of a somehow various individual. Therefore, the 'Other' was debased to the representation of absolute evil behavior and barbarism that serves to empower the notions of a developing 'Englishness' and also a Christian unanimity intending to suppress the internal conflict. As a result, public biases along with concepts of villainous Jewish-Moorish inclinations were abused obviously in many plays of that period.

What has made Othello and The Merchant of Venice so eternal and endless is Shakespeare's deviation from tradition in the representation of the Jew Shylock and the Moor Othello as the true embodiment of 'Otherness.' Othello and Shylock have some features related to Moors and Jews during the Elizabethan period is undeniable. Othello, insanely jealous, commits a brutally vicious murder, and Shylock is a usurer fond of financial values intending to take horrible revenge on a Christian individual. It should not be ignored that even if Othello and Shylock to some extent match up to traditional stereotypes, this fact is constantly highlighted throughout the course of both plays that the things which mark Othello and Shylock as specifically brutal 'Other' are not because of the internal inhumanity and savagery, rather it seems that to a very great extent both characters are provoked to such deeds by the unfair exclusion and marginalization of them from the Elizabethan society as other.

\section{Othello vs. Shylock}

At the beginning of the plays, both Othello and Shylock are described in their bare 'Otherness.' Othello is the black Moor living in a white community; and, likewise, Shylock is a Jew in a Christian society. Aside from these similar distinctive qualities, nevertheless, their conditions were poles apart. Othello has apparently adapted to Venetian community extremely well and is persuaded of the feasibility of complete integration. He has become a Christian and when chosen as a general he is a valued and praiseworthy individual of the society, which is obvious, for example, in his constant invitations to have dinner with senior senators. The black color of his skin is considered as an attractively interesting and secretive attribute rather than something hateful. Shylock, on the contrary, lives the lonely life of an isolated stranger completely excluded from the rest of the Christian society. He is aware of the fact that he will never ever be capable of integrating in that society. He undergoes constant spoken and physical attacks by the Venetian Christians that obviously hate him for merely being a Jew, and then, because of his usury. While Othello entirely adapts to the Venetian community and considers himself as a valued member of it, Shylock rejects any efforts to adapt himself to that Christian society. A crucial turning point happens to both characters when Othello secretly marries Desdemona, and Jessica, Shylock's daughter, manages to flee. That is actually the elopement of the two daughters; one into the arms of the black foreigner, the 
other kidnaped of her own free will by an individual from the Christian society. Othello, who has married the beautiful white senator's daughter as the thorough manifestation of his inclusion and integration, is suddenly faced with apparent aggression and dislike. He must recognize the fact that he can integrate and harmonize on a high level of standard that is serving the Venetians, but must be wise enough not to go beyond cultural borders by marrying Desdemona who is a Venetian noble girl.

When Jessica defies her father by eloping with her beloved, Shylock loses his last emotional shelter keeping him away from violence and biased actions from the Christian society. When Shylock finds out that his daughter, Jessica, has not only been unfaithful to him in favor of a Christian guy hating him but also she has stolen a ring from him, he is devastated and left alone in sheer unfriendliness and isolation. After that, Shylock is determined to take revenge and little by little converts into that cruel monster. Othello, likewise, is extremely troubled by the unforeseen aggressions against him. Quickly losing his confidence, he is victimized by Iago's trickery that instantly abuses Othello's alienism to Venetian nation in achieving his own wicked goals. Cleverly, he abuses Othello's increasing concerns emphasizing that it is unusual for a young beautiful white girl to love an older black man and that he is an alien who is not familiar with the Venetian women's dishonorable infidelity. Unfortunately, Iago rapidly succeeds in driving Othello insane who decides firmly for revenge.

Shylock, also, vows to take revenge. Yearning to do that and cursing Jessica for that theft, he nevertheless causes us to sympathize with him when he expresses profound passionate commitment to his ring that Jessica has traded in return for a monkey and which he had considered as a treasury reminding him of his deceased adorable wife. When he grieves about his turquoise theft, however, his grief appears to stem from the depth of his heart, making him an interesting character and making his intentions about taking revenge thoroughly comprehensible and rational.

Contrary to Shylock, Othello that has formerly been shown as a decorous man, worsens bereft of anything to recover from insanity, most obviously shown by his progressively unreasonable language. Being persuaded that Desdemona is guilty and unfaithful, his previously pleasant view of the world ruins and he is completely devastated. Berry asserts that Shylock has his Jewish background, Othello is thoroughly devastated. According to Berry,

The Moor's alienation goes much deeper than Shylock's [...]. Othello sees himself either as an exotic Venetian, a convert in the fullest sense, capable of complete assimilation, or he sees himself as a barbarian, worthy of destruction. His failure [...] to achieve a true sense of personal identity is one of the play's most powerful sources of tragic feeling. (Berry 323)

Eventually, Othello kills his innocent wife cruelly because of his jealousy, and Shylock angrily insists on his absolute right to take revenge. When he understands his 
main tragic fault his life ruins completely, but then his harmonious view of the world concerning good and evil that was obviously illustrious is now repaired. Regretful and distressed he takes his own life defining himself as a prominent and brave Christian soldier and as a cruel evil at the same time. After that bitter incident of his suicide he is remembered as a man with a great heart indicating that Othello was a tragic hero and not a brutal evil.

Shylock's character is described as more vaguely. Claiming his right to revenge he is representative of the ancient law that is replaced by more up-to-date notions of impartiality and justice. Shylock, contrary to Othello, does not admit his fallacies but has no other way but to be converted compulsorily to Christianity if he wants and desires to be kept on the straight and narrow. Even though one might consider that Shylock's fate is less sad than Othello's destiny because Shylock does not end up losing his life at the end, it must be noted that Shylock becomes alone with a broken heart alienated from the rest of the happy society of the Christians but Othello, despite the fact that loses his life, is redeemed.

All in all, it must be mentioned that though the two most well-known 'Others' of Shakespeare's plays are different not only in terms of their conditions but also in the way they try to cope with their 'Otherness', both of them finally desire to be accepted by the Venetian community. Being deprived of their rights as equal individuals they are sorely made cognizant of their 'Otherness' that cannot be eliminated laying foundations for the things that determine their bitter fate. Furthermore, both plays presented that exterior and the interior of the things may be completely different and that how regularly formerly acknowledged notions could be proved as wrong. In Othello it is not Othello, but Iago the same white man who lacks any decency and morality, showing that real cruel and hateful 'black devil'. In The Merchant of Venice, also, the Christians are somewhat acting against the expectations on them as supposedly ethically better than the Jews. Throughout the course of the play, the Christians themselves commit the same flaws that they hate Shylock for including, some of them are fond of money and some are reluctant to have compassion for those different from themselves.

Unlike numerous characters of his contemporaries and even most characters of his successors, Shakespeare's characters do not merely represent one specific virtue or vice but are almost all many-sided and multidimensional. Schabert asserts that "Molière's miser is miserly", he adds "and no more; Shakespeare's Shylock is miserly, shrewd, vengeful, child-loving and witty." (Schabert284).

\section{Deconstruction of Marriage in Othello}

Through the marriage of Othello and Desdemona Shakespeare wants to say implies that the assimilation of self and other is not possible. Desdemona is white and European, she stands for Europe Othello is black and Moorish. He stands for Africa. Therefore the union of Africa and Europe or the union of west and east is not feasible as the marriage is a failure the union is a fiasco too. Shakespeare in writing Othello is telling us that it is not natural for two people of different races to fall in love. It is against 
the nature as the play suggests:

"and she, in spite of nature,

Of years, of country, credit, everything,

To fall in love with what she fear'd to look on!" (Oth. 1.3.96-98)

The text is teaching us that the union of Othello and Desdemona or their union is not at all natural. This is what Shakespeare in this play tells us. Through the marriage of these two people he has a political idea in mind that it is not good to marry an African. The text uses the word 'nature' to say it is not possible and natural to have such a marriage, however the history is full of such marriages and it is not against nature and many religions do not accept such racist ideas. The above text is very racist; it creates a binary opposition of beautiful and ugly, white and black giving privilege to the first term. Othello is full of insult directed at Othello like "old black ram", "the devil", "Barbary horse" and "the beast with two backs", "lascivious Moor", "foul thief", "bond-slave", "pagan", and "the blacker devil". These words are racist words considering the fact that Othello is an African. Shakespeare through this marriage insults Othello and the people of whom Othello is a type. These people are nobody but African belonging to east part of the world.

Shakespeare's othering Othello is very intense in these very lines where Shakespeare wants Othello to say:

Haply, for I am black,

And have not those soft parts of conversation

That chamberers have, or for I am declin'd

Into the vale of years (yet that's not much),

She's gone. I am abus'd, and my relief

That we can call these delicate creatures ours,

And not their appetites! I had rather be a toad

And live upon the vapor of a dungeon

Than keep a corner in the thing I love

For others' uses. Yet 'tis the plague [of] great ones,

Prerogativ'd are they less than the base;

'Tis destiny unshunnable, like death.

Even then this forked plague is fated to us

When we do quicken. (Oth. 3.3.263-77)

Shakespeare implicitly attributes the evil deeds to black people. He others the African in the Venice which is a major city of Europe. Through this marriage Shakespeare marginalizes African more and more and attributes devil and satanic things to them. Shakespeare says in the binary opposition of European and African, Europeans are better and superior while the African are evil and inferior, this is absolute racism.

Othello's real color becomes clear eventually. When he murdered Desdemona, 
Emilia, Iago's wife, enters the scene and looks at Desdemona that is dying. Desdemona tries to save Othello's life by telling Emilia that she took her own life, but Othello says, "she's like a liar gone to burning hell! 'Twas I that killed her" (Oth. 5.2.159-160). He somehow is illustrating that black men are aggressive and everyone must be fearful of them. Emilia replies that, "O, the more angel she, and you the blacker devil!" (Oth. 5.2.161). It is patently clear that in her opinion Othello's moral virtues and ethics are reversed regarding that white is black and black is white. Emilia observes a reversed form of Othello, an evil guy who tricked the white beautiful girl into falling in love with him.

After Othello understood that he had actually been deceived by Iago and his wicked lies, he couldn't cope with the agony of the fact that he murdered his wife because of jealousy and not justice. Consequently Othello's character is ruined, but he brings back the great and brave soldier of Act I. Before committing suicide, he said the following words:

No more of that. I pray you in letters,

When you shall these unlucky deeds relate,

Speak of me as I am. Nothing extenuate,

Nor set down aught in malice. Then must you speak

Of one that loved not wisely, but too well;

Of one not easily jealous, but being wrought,

Perplexed in the extreme; of one whose hand,

Like the base Judean, threw a pearl away

Richer than all his tribe; of one whose subdued

eyes,

Albeit unused to the melting mood,

Drops tears as fast as the Arabian trees

Their medicinal gum. Set you down this (Oth. 5.2.402-412)

\section{Deconstruction of Marriage in The Merchant of Venice}

In the case of Marchant of Venice marriage becomes a discourse through which the writer insults others and makes otherization of other races. In the case of The Merchant of Venice, Portia has many suitors. The suitors are from different nationality.

All the world desires her.

From the four corners of the earth they come

To kiss this shrine, this mortal-breathing saint.

The Persian deserts and the vasty wilds

Of wide Arabia are as thoroughfares now

For every prince to come and view fair Portia. (MV 2.7.38-42)

Among the suitors, there is one who is not a European one; he is a prince from Morocco. Shakespeare in stage directs introduces him as 'a dark-skinned Moor dressed 
in white'. He comes to pop the question. He has come from Morocco to propose to Portia. The first sentence which he utters is related to his dark complexion:

Mislike me not for my complexion;

This darkened raiment of the burnished sun

Is worn by all who breed so near its fire.

Bring me a man whose skin is light and fair,

Born from the coldest regions of the north,

Where the sun's heat can scarce thaw an icicle

And let us make a cut, at love's behest,

To prove whose blood is reddest - his or mine.

I tell thee, lady, this aspect of mine

Has brought much fear to brave and valiant men.

And by my love, I swear, it too was loved

By the most-honored virgins of our clime.

I would not change this dark and noble hue,

Except to steal your thoughts, my gentle queen. (MV 2.1.1-12)

The elegant explanation of the prince of Morocco makes for his dark coloring functions in order to call attention to it, to lay emphasis on it and to his cultural difference from Portia and from Shakespeare's audience. His excessive praise of his own valor also makes him seem both less well-mannered and less attractive. Moreover, his assertion that the best virgins of his clime have loved him seems designed by Shakespeare to make him less, rather than more, good-looking and attractive to Portia. This passage shows that skin color matters not only to Portia but Shakespeare himself. The question is that now that it matters to Shakespeare why he has chosen a suitor with this complexion considering Portia's dislike of the prince of Morocco. In response to what the prince of Morocco says, Portia says:

In terms of choice I am not solely led By nice direction of a maiden's eyes.

Besides, the lottery of my destiny

Bars me the right of voluntary choosing.

But if my father had not scanted me

And hedged me by his wit to yield myself

His wife who wins me by that means I told you,

Yourself, renownèd Prince, then stood as fair

As any comer I have looked on yet

For my affection. (MV 2.1.13-22)

The text over again deconstructs itself in terms of the marriage of Portia. If she has no control over the process of choosing her husband why does she say in the previous scene that: "And if he [the prince of Morocco] had the temperament of a saint 
and the complexion of a devil, I had rather he should hear of my strife than take me as a wife" (MV 1.2.120-122). This is in contradiction to what she says to the prince of Morocco in the above lines. Here she shows herself as innocent as possible but in the previous scene she is totally racist. The text informs us that she has no control over the marriages, but she shows her hatred of the prince of Morocco and names him 'devil' in order not to marry him. With a lengthy proclamation of his own bravery and heroism, the prince of Morocco says:

Even for that I thank you.

Therefore, I pray you, lead me to the caskets

To try my fortune. By this scimitar

That slew a Sultan and a Persian Prince,

That thrice defeated the great Suleiman,

I would o'er-stare the sternest eyes that look,

Outbrave the boldest heart that e'er did beat;

Pluck the young suckling cubs from the she-bear,

Yea, mock the lion when it roars for prey,

To win thee, lady. But alas the while,

If Hercules and his servant play dice,

The hand of chance decides the better man

Which may grant victory to the weaker hand:

So is the hero beaten by his page.

And so may I, blind fortune leading me,

Miss that which one of lesser worth attains-

And die with grieving. (MV 2.1.22-38)

She has the least admiration for what the prince of Morocco has done. She does not praise him instead she warns him that:

You must take your chance,

And either not attempt to choose at all,

Or swear before you choose, if you choose wrong,

To ne'er thereafter take a lady's hand

By way of marriage. Therefore, be advised (MV 2.1.40-44)

This is crystal clear that she does not want him as her husband and for this very reason she advises him not to take the chance at all. The reason she does not want her as her spouse is his complexion and his being a non-European personality. He is not from the same race that she is. He is a Moroccan and she is Venetian. He is an 'other'; an 'other' whose assimilation to the self is out of the question. This will reveal the intention of Shakespeare that his text deconstructs itself and by this deconstructing we get to the bottom of his ideology and the dominant discourse of the Elizabethan time. To deconstruct the text, we ask some question as Derrida the forerunner of Deconstruction 
would ask: If the prince of Morocco has chosen the right casket what would have happened? Why not to choose the right casket on the part of the prince of Morocco? Why has Shakespeare chosen the prince of Morocco while Portia hates him? The prince of Morocco has come in an attempt to pick the right casket to marry her. The prince studies the writings on the three caskets and chooses the gold one, which proves to be not the correct choice. The case is very tricky and dangerous. Because the way the prince of Morocco chooses the gold casket shows his humiliation.

Never so rich a gem

Was set in worse than gold. They have in England

A coin that bears the figure of an angel

Stamped in gold; but that's in sculpted upon

The surface - here an angel lies within!

Deliver me the key, and straight away

Here do I choose, and prosper as I may. (MV 2.7.58-64)

This is the reasoning of the prince of Morocco. However when he opens the golden casket, he is taken aback by the skull inside the golden casket. Inside the golden casket is a note which reads:

All that glitters is not gold;

Often have your heard that told.

Many a man his life hath sold,

For the outside to behold,

Gilded tombs do worms enfold.

Had you been as wise as bold,

Young in limbs, in judgment old,

Your answer had not been inscrolled-

Fair you well, your suit is cold (MV 2.7.69-77)

The note is a note of humiliation intended for the prince of morocco. When he leaves the palace Portia very happy because the prince of Morocco chose the wrong casket insults the prince of Morocco because of his skin color:

A gentle riddance. Draw the curtains, go-

Let all of his complexion choose me so (MV 2.7.82-83)

She is very arrogant and indecent to people like the prince of Morocco. She insults the price of Morocco. She makes the prince of Morocco and all the people 'of his complexion' other. This othering based of marriages reveals something about her. If we take her as the synecdoche of a part for the whole we see she is Europe itself and prince of Morocco is the part for the whole of Africa. All the text and all Shakespeare implicitly want to say is that the union of Europe and Africa is not proper as symbolized in the marriage as well as the union of Portia and the prince of Morocco which never happens. 
Through this strange choice of marriage the prince is made a fool. He is not first of all logical, reasonable and wise to choose the right casket and second of all he is attracted to Portia because he thinks she is his equal. Shakespeare reinforces this otherization of the other. He repeats the discourse of otherization as it was dominant in his time because the European considered themselves as superior and wise and reasonable to other races. This is evident in all of Shakespeare's writings. As Edward Said has also shown in his great book 'Orientalism' the west has always made itself better than the east, and has known itself as better. Prior to the coming of the prince of Morocco, Portia, when hearing he is going to come to ask her hand in marriage, says:

If I could bid the fifth welcome with so good a heart

As I can bid the other four farewell, I should be glad

Of his approach. If he have the condition of a saint and

The complexion of a devil, I had rather he should

Shrive me than wive me. (MV 1.2.118-122)

This passage foreshadows and predicts that Portia will not choose him. Therefore the system of marriage is intended to insult others like the prince of Morocco. The text itself deconstructs itself; it says what it does not mean. What if the prince of Morocco chose the right casket? The writer and the character do not give a damn to chance and they already know who the real suitor is. Certainly Shakespeare does not intend the prince of Morocco as Portia's husband. This is evident from the words of Portia. The text says she should choose according to the will of her father and the will of her father states that the one who chooses the right casket is the real husband of Portia. But prior to this picking and choosing she has rejected the prince of Morocco based on his skin color. This is where the text has a hole in itself. By deconstructing this marriage we see the ideology behind the text of The Merchant of Venice. The ideology is that the European race is considered superior to other races and this is shown in the choice of Portia as a beautiful girl. We can further deconstruct the play by saying and asking why didn't Shakespeare choose an ugly European girl instead of Portia. The answer is too clear, because a beautiful European girl can play the role better than an ugly one when it is the question of assimilation of races.

The prince of Morocco is included among 'foolish multitude' and 'barbarous multitudes' by William Shakespeare when the prince of Arrogan is about to choose. The prince of Arrogan when examining the gold casket says:

"What many men desire" that "many" may be meant

By the fool multitude that choose by show,

Not learning more than the fond eye doth teach;

Which pries not to th' interior, but like the martlet

Builds in the weather on the outward wall,

Even in the force and road of casualty.

I will not choose what many men desire 
Because I will not jump with common spirits

And rank me with the barbarous multitudes. (MV 2.9.24-32)

The prince of Arrogan does not choose what the prince of Morocco chose. Here in the above lines Shakespeare through the words of the prince of Aragon otherizes the prince of Morocco and labels him as fool. If we take the prince of Morocco as the synecdoche of a part for the whole African, the 'foolish multitude' and 'barbarous multitudes' will become the whole Africa, an insult intended to otherize African people.

Even having a lot of suitors from different nationalities signifies the fact that she, as a symbol of Europe is desirable by many other nations and they want to unite with Europe, here Europe becomes self and other nations become other.

All the world desires her.

From the four corners of the earth they come

To kiss this shrine, this mortal-breathing saint.

The Persian deserts and the vast wilds

Of wide Arabia are as thoroughfares now

For every prince to come and view fair Portia. (MV 2.7.39-44)

At the end we see that Europe is not united and should not be united with other nations and should not be equal with other nations. She loves Bassanio who is from Venice and that is the entire question. She even gives clue to Bassanio to choose the lead casket. Even the process of choosing is problematic because one who chooses the right one is intelligent, smart, and above all wise. This process is not even based on love, we can deconstruct it because love is not based on choosing love, rather it is a kind of feeling that somebody has towards his/her partner. Love is something somebody falls into not something which somebody chooses.

\section{Racism in Othello}

Racism did exist in Elizabethan period. The foreign travels and familiarizing with other races and different people happened very rarely during that era. The majority of England's population could not cope with dissimilar races and groups and therefore "blacks -were- monsters, strange creatures from outside the boundaries of the world" (Aubrey 76).

In her book, Shakespeare, Race and Colonialism, Ania Loomba says that in the Renaissance perception, the Arab moors that had a brighter skin complexion, benefited from some religious and cultural heritage; while, Sub-Saharan Africans were"...associated with a lack of religion and culture, and painted as low-born" (Loomba81). The mentioned stereotype was a strong cause behind the rapid-growing slave trade that supported and kept the Empire going for centuries. Representing the black-complexioned community as barely human was essential to lay foundations for the slave trade among the "superior" whites.

The power of Othello's sensitivity stems from the strength of his suspicion and 
jealousy. Blackness was associated with savagery and barbarity in the minds of the European perceptions. Sukanta Chaudhuri in Infirm Glory indicates says that Othello's great power "springs startlingly close to the sources of animal energy, the feritas in man" (Chaudhuri 164). Othello's tragic end is caused by an unawareness of worldly sin. Othello's virtues are in fact by far more than his vices. When he realizes his sin, he severely punished himself with an aggressive death. At this point his inherent decency, moral principles, and dignity once again are represented.

\section{Racism in The Merchant of Venice}

The Merchant of Venice, particularly the character of Shylock, was considered to give credibility to anti-Semitic notions of cultural segregation. For example, James Shapiro in his article "Shakespur and the Jew bill" highlights the unknown fact that, "Seasonable Remarks on the Act Lately Passed where this work of Shakespeare is used as an evidence to indicate that Jews are innately different" (Shapiro 132).

Shakespeare definitely had a significant perception in his mind in displaying Shylock as a savage, and in showing Othello at the beginning as a noble man but at the end leads him to those brutal actions. Lawrence Lerner in a quotation from Martin Orkin's article indicates that, "I am afraid Shakespeare suffered from color prejudice..."(Orkin 184).Walter Poznarin his article says:

What Shakespeare's conscious motive may have been we will never know, but there is little doubt that the stereotype he began with has grown beyond its conventional form, has found a richer voice than that of Barabas, has touched a deeper dramatic chord than any Shakespeare might have anticipated when he first ushered Shylock [et. al.] onto the stage. (Poznar 311)

Shylock is obviously treated like an outcast in this community, he is not considered as a member among the people, but a lonely alien. The bitter words that he hears from almost each single member of that society is no less than utter ill-treatment. Derek Cohen asserts that:

The word Jew is used 55 times in The Merchant of Venice. Variants of the wordlike Jewess, Jews, Jew's, and Jewish are used 14 times; Hebrew is used twice. There are, then, 74 direct uses of Jew...in the play....Shakespeare understood the drayaticand rhetorical power of iterating repetition), it must follow that there is a deliberate reason for the fervency of the word in the play. (Cohen 106)

Shakespeare could be regarded as hypocritical because he, as a renowned literary figure, never tries to correct the unfair treatments committed unfairly against Shylock the 
Jew. The message at the end of Act IV is implying that these people are, as a matter of fact, monsters and as a result they could not be treated with justice like the way the majority of the people in society, the Christians, were. Some might think that maybe Shakespeare did not share the Elizabethan society's hatred toward Jews, but the fact is that Shakespeare implicitly was supporting that society's point of view by writing these prejudiced plays without condemning these unfair treatments of the Jews in his plays.

\section{Final Considerations}

The study aimed to analyze the construction of racism and the evidences of discrimination as represented in Othello and the Merchant of Venice by means of the deconstruction of marriage, focusing on Othello and The Prince of Morocco in Othello and The Merchant of Venice. The critical analysis reveals that definitely there is nowhere in the whole world where people undergoing different kinds of discrimination, including racial discrimination like Othello, religious discrimination like Shylock, enjoy their life in a state of both mental and physical health.

In Shakespeare's Othello and The Merchant of Venice, we see two marriages which are intended to marginalize African people. We also see the confrontation of west and east. In Othello Shakespeare refers to Desdemona who is worth Othello's tribe and in The Merchant of Venice Shakespeare refers to Portia as a gem. Both of these women are European. While for Othello and the prince of Morocco Shakespeare uses the words 'fool' and 'thick lip' and many other races. The union of Othello and Desdemona is a failure by which Shakespeare practically teaches a lesson to his European audience that the blacks and hence Africans are jealous, illogical, and crazy. In The Merchant of Venice Shakespeare says, when deconstructed, a gem a beautiful European girl does not suit a black ugly prince of Morocco. Therefore, marriage becomes a tool through which Shakespeare gives life to the binary opposition of white and black and further reinforces the separation which this binary, according to the what this study discussed, is very reversible and deconstructable in a way that one could make sure there will be no white if there will be no black.

The condition of human beings such as, their mind and their body can certainly be considered as a very unsteady and delicate construction. This special construction is what distinguishes human beings from animals making them superior to animals, but this superiority does not refer to one group of human beings over another group of human beings. Human beings have been given two distinguishing features, the ability to 'think/reason' along with the power of 'speaking'. Human beings, in many cases, are capable of communicating with each other expressing what they have in their mind, what they think of, and write them all down on a piece of paper. Each single human being throughout this world has a responsibility and duty to the other human beings in that they have to think/reason carefully before they express their concealed thoughts. They should, furthermore, think cautiously before writing down their ideas on a paper. Human beings possess the ability to hurt other human beings' feelings by means of what they express or even by what they write down on a piece of paper like the way Shakespeare did by 
writing his two plays mentioned in this article. There exists remarkable responsibility while writing a piece of art. Whether the words are written or spoken, they have great power. Shakespeare, unfortunately, failed to understand, or probably he realized what he was doing but did not listen to the voice of his conscience. Therefore in uttering one single word, writing down a simple informal letter, and most importantly in creating a work of art one should be careful not to hurt other people's feelings by being biased and racist. When it comes to the great literary figures of the world, this responsibility becomes more important since their literary masterpieces will remain and live centuries after the author is passed away but unfortunately the bitter results and repercussions will remain forever hurting the feelings of numerous people throughout the whole world.

\section{Works Cited}

Aubrey, James.“James R. Aubrey on Monster Imagery and Racism in Othello.” Bloom's Notes. 1999, 76-79.

Berry, Edward. “Othello's Alienation.”Studies in English Literature 1500-1900. 1990, 30.2: 315-333.

Chaudhuri, S. Infirm Glory: Shakespeare and the Renaissance Image of Man. Walton

Street: Oxford University Press, 1981.

Cohen, David K."Shylock and the Idea of the Jew."ShakesmareanMotives.London:

MacMillan Press, 1988.104-118.

Dollimore, Jonathan. Radical Tragedy: Religion, Ideology and Power in the Drama of

Shakespeare and his Contemporaries. 2nd ed. New York: Harvester Wheatsheaf, 1989.

Hall, Stuart. "The Spectacle of the 'Other'." In: Stuart Hall, ed. Representation:Cultural

Representations and Signifying Practices. London: SAGE Publications, 1997, 223-279.

Loomba, A. Shakespeare, Race, and Colonialism. Oxford: Oxford University Press, 2002.

Orkin, Martin."Othello and the 'Plain Face' of Racism."Shakespeare Quarterly

38.2(Summer 1987): p166-188.

Poznar, Walter."Shylock and the Social Order." The Centennial Review 26.3(Summer 1982): p302-311.

PRIOR, MOODY E. "Which Is the Jew That Shakespeare Drew? Shylock Among the

Critics." The American Scholar, vol. 50, no. 4, 1981, pp. 479-498. JSTOR, www.jstor.org/stable/41210764.Accessed 24 Feb. 2021.

Schabert, Ina. "Die theaterbezogeneKunst." In: Ina Schabert, ed. Shakespeare

Handbuch: Die Zeit - Der Mensch - Das Werk - Die Nachwelt. Stuttgart: Alfred Kröner, 2000.243-298.

Shakespeare, William, 1564-1616. The merchant of Venice. Harlow, Essex, England:

Longman, 1994. 
Shakespeare, William, 1564-1616. Othello : 1622. Oxford :Clarendon Press, 1975.

Shapiro, J. "Shakespur and the Jewbill." In Shakespeare and Race, edited by Catherine Alexander and Stanley Wells. Cambridge: Cambridge University Press, 2000.

Staszak, Jean F. “Other/Otherness”. In: International Encyclopedia of Human

Geography. Eds. Rob Kitchin, and Nigel Thrift. Vol. 8. Amsterdam: Elsevier. 2009.43-47.

Vitkus, Daniel J. "Turning Turk in Othello: The Conversion and Damnation of the Moor." Shakespeare Quarterly. 1997.48.2: 145-176.

\section{The Author}

\section{Shaghayegh Moghari}

Semnan University, Iran

E-mail: shaghayeghmoghari@gmail.com

\section{The Article}

Date sent: 19/04/2021

Date revised: 08/07/2021

Date Accepted: 13/07/2021 